\title{
Effect of pituitary gland doses on induced breeding of Crucian Carp, Carassius carassius
}

\author{
M. S. Ali*, M. G. S. Riar, M. F. Siddique and Y. Mahmud \\ Bangladesh Fisheries Research Institute, Freshwater Station, Mymensingh-2201, Bangladesh \\ *E-mail: drmdshaha_ali@yahoo.com
}

\begin{abstract}
Induced breeding of crucian carp, Carassius carassius was conducted in order to determine the optimum dose of pituitary gland (PG) hormone. The research was done at the hatchery of the Freshwater Station, Bangladesh Fisheries Research Institute, Mymensingh. The study was consisted of four different doses of $P G$ treatments ( $T_{1}, T_{2}$, $T_{3}$ and $T_{4}$ ) with three replications of each. In the experiment single dose was used for $T_{1}$ while double dose used for $\mathrm{T}_{2}, \mathrm{~T}_{3}$ and $\mathrm{T}_{4}$ to evaluate the efficiency of PG hormone on ovulation, fertilization and hatching rates of $C$. carassius eggs. Single dose of $6.0 \mathrm{mg} \mathrm{PG} \mathrm{kg}^{-1}$ body weight (bw) of female fish had no ovulatory response. The double dose in case of female fish in $\mathrm{T}_{2}$ at the rate of $6.0 \mathrm{mg} \mathrm{PG} \mathrm{kg}^{-1} \mathrm{bw}\left(1^{\text {st }}\right.$ dose 1.0 and $2^{\text {nd }}$ dose $5.0 \mathrm{mg} \mathrm{PG} \mathrm{kg}{ }^{-1} \mathrm{bw}$ at $6 \mathrm{~h}$ interval) and $2.0 \mathrm{mg} \mathrm{PG} \mathrm{kg}^{-1}$ bw of male fish (single dose during the time of $2^{\text {nd }}$ injection of female) in January showed better results in terms of ovulation (96.52 $\pm 1.53 \%)$, fertilization $(90.35 \pm 1.67 \%)$ and hatching rates $(78.65 \pm 2.84 \%)$ compared to other treatments. Considering ovulation, fertilization and hatching rates the double dose of $6.0 \mathrm{mg} \mathrm{PG} \mathrm{kg}^{-1} \mathrm{bw}$ of female and single dose of $2.0 \mathrm{mg} \mathrm{PG} \mathrm{kg}{ }^{-1}$ bw of male can be used in induced breeding of $C$. carassius during January. The findings of this study indicated that induced breeding of $C$. Carassius is successful through PG extract and might be useful for large scale seed production in the hatchery operation.
\end{abstract}

Keywords: Induced breeding, PG, Carassius carassius

\section{Introduction}

Crucian carp, Carassius carassius is the only fish species found in the shallow ponds of Northern and Eastern Europe, due to its ability to survive hypoxic conditions during winter by anaerobic metabolism of glycogen stored principally in the liver (Holopainen and Hyvärinen, 1985). It is a medium-size sedentary fish with a moderate growth rate that can be cultured in poly and monoculture system in various aquatic environments viz., lakes, rivers, reservoirs and slow moving waterbodies. This species reach marketable size (150-1250 g) within 6-12 months. It is basically an omnivore that naturally feeds on organic detritus, filamentous algae, small benthic animals and seeds of aquatic weeds. In addition, in aquaculture, they accept artificial feed such as by-products from grain processing and oil extraction and pelleted feed. They can propagate naturally in various waterbodies and induced breeding is very easy.

Introducing of suitable fish species for enhancing production is the common practice in Bangladesh. Crucian carp, Carassius carassius (Figure 1) is first time introduced in Bangladesh Fisheries Research Institute (BFRI) on July 2010 from China. This could be a very suitable species for the aquaculture in Bangladesh. The seed production technology is the prerequisite of development of culture technique. In Bangladesh, artificial breeding of endemic carp seed has become a common practice since 1967 (Ali, 1967). Many researchers worked on the induced breeding of carps included Haque, 1975; Islam \& Chawdhury, 1976; Alikunhi et al. 1960; Chaudhuri, 1960; Sinha, 1971; Alam and Bhuiyan,1999 and Bhuiyan et al. 2008. Exotic carps have also been introduced. A large number of hatcheries in the private sector (estimated more than 900) have been established (DoF, 2013). These private and a smaller number of state hatcheries presently contributing about $99 \%$ of the total spawns production and meet up the demands of seeds in the aquaculture in Bangladesh. However, before going to start large scale culture practices of any newly introduced species of fish, it is necessary to establish reliable induced breeding techniques in our aquaculture. 
The spawning of $C$. carassius takes place at more than $17^{\circ} \mathrm{C}$ and the eggs are laid in $2-3$ batches (Holopainen and Hyvärinen, 1985). Spawning behaviour of goldfish and crucian carp were induced by injection of prostaglandin to females (Kobayashi et al., 2002). Considering its biology and growth along with high taste and market demands $C$. carassius can be treated as a promising cultured species in the aquaculture of Bangladesh. Before going large-scale culture practices of this species the first and foremost work has been selected on induced breeding to ensure the production of stokable sized seeds. No work has been conducted on the culture practice or induced breeding of $C$. carassius in Bangldesh. Therefore, the present work has been under taken with the objectives viz., to determine the optimum dose of PG hormone for induced breeding of $C$. carassius and to develop a protocol for its large scale breeding.
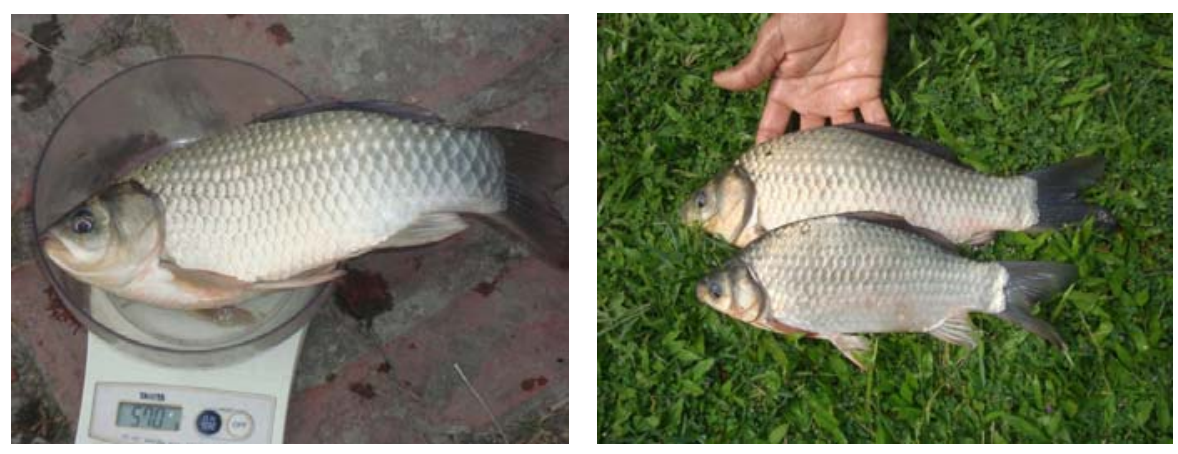

Fig. 1. Crucian carp (Carassius carassius)

\section{Materials and Methods}

The experiment was conducted in the carp hatchery of the Freshwater Station, Bangladesh Fisheries Research Institute, Mymensingh during the period of October 2013 to January 2014.

\section{Collection of fish}

About 500 C. carassius fingerlings (average weight $15.66 \pm 2.11 \mathrm{~g}$ ) were imported from China through Commerce Ministry of the People's Republic of Bangladesh. The fish was reared up to the maturity stages (18 months) in the earthen ponds. During rearing period the fish were fed with commercial pelleted fish feed ( $25 \%$ protein) at the rate of $3 \%$ body weight (bw) once a day.

\section{Maintenance of brood stock}

Two hundred C. carassius matured (males and females) were selected from this imported stock. Three months prior to conduct induced breeding experiments the mature males and females broods were stocked in separate ponds during the period from October to December, 2013 and reared up to ready to spawn. Selected broods were fed with commercially available pelleted fish feed (28\% protein) at the rate of $4 \%$ bw day $^{-1}$ (twice a day between 9:00- 9:30 $\mathrm{h}$ in the morning and between 16:00- 17:00 $\mathrm{h}$ in the afternoon).

\section{Brood selection}

When the fish attained ready to spawn 32 females and 32 males brood fish were selected based on physical and visual examination of secondary sexual characteristics i.e. the mature females could be easily identified by their swollen abdomen and round or oval and swollen urogenital papillae. On the other hand, the mature males were identified by their flat abdomens and long protruded genital papillae and milt was also seen when gently pressed their abdomens. Only healthy and uninjured fishes were selected for artificial breeding. The average weight of the females and males were ranged from 455-456 $\mathrm{g}$ and 550$568 \mathrm{~g}$, respectively (Table 1 ). 


\section{Conditioning of the brood fish}

Broods were collected from the brood rearing ponds in the early morning. Selected female and male broods were weighed and kept in separate cisterns for 6-8 $\mathrm{h}$ for conditioning before treated with PG extract. During conditioning continuous water flow was provided through inlet for aeration to ensure sufficient dissolved oxygen to the stocked brood fish in each cistern.

\section{Experimental design}

The induced breeding experiment consisted of four different doses of PG treatments $\left(T_{1}, T_{2}, T_{3}\right.$ and $\left.T_{4}\right)$ with three replications of each treatment. A total of 32 females and 32 males were selected for the injection. The females under each treatment were set-up under three replications indicated as $R_{1}, R_{2}$ and $R_{3}$ and kept in separate cistern. The females under $T_{1}, T_{2}, T_{3}$ and $T_{4}$ were injected with PG extract at the dose of 6.0 (single dose), 6.0, 7.0 and $8.0 \mathrm{mg}$ (double dose) $\mathrm{kg}^{-1} \mathrm{bw}$ of fish, respectively. In case of males under $\mathrm{T}_{1}, \mathrm{~T}_{2}, \mathrm{~T}_{3}$ and $\mathrm{T}_{4}$ were injected at the dose of $2.0,2.0,2.5$ and $3.0 \mathrm{mg} \mathrm{PG} \mathrm{kg}{ }^{-1} \mathrm{bw}$, respectively. For the female fish the double dose was divided into two volumes and injected at $6 \mathrm{~h}$ interval and the males were injected with single dose during $2^{\text {nd }}$ injection of females. After ovulation, eight females and eight males from each treatment were selected for stripping.

\section{Preparation of PG doses}

Locally available dry carp pituitary glands (PG) were collected from market in preserved condition in airtight vials. To prepare the extract for injection the required amount of PG was carefully weighed out in an analytical electronic balance. The amount of PG required was calculated on the basis of body weight of all the fish of a particular treatment to be injected using the formula as: Weight (mg) of required amount of PG $\left(W_{t}\right)=W_{b} \times P_{t}$, Where, $W_{b}$ represents total body weight $(\mathrm{kg})$ of all the fish to be injected; and $P_{t}$ represents the rate in $\mathrm{mg}$ of $P G$ to be injected $\mathrm{kg}^{-1}$ bw under a particular treatment. The total volume of the extract required was calculated by the formula as: Vol. of extract $(\mathrm{ml})=\mathrm{W}_{t} \times 1.0$, Where, $\mathrm{W}_{t}$ represents the weight of $P G(\mathrm{mg})$; and 1.0 represents the volume of the extract in $\mathrm{ml}$ to be injected $\mathrm{kg}^{-1}$ bw of fish. The weighed PG was homogenized with a small volume of distilled water and the homogenate was carefully transferred to a centrifuge tube by using distilled water to ensure complete transfer. The mixture was centrifuged for $6 \mathrm{~min}$. at $6000 \mathrm{rpm}$. The freshly prepared supernatant solution of PG hormone was then slowly loaded in graduated $1.0 \mathrm{ml}$ hypodermic syringe for injection.

\section{Method of injection of PG dose to the fish}

The selected brood fish were caught very carefully from the spawning tank and put on foam for injecting the PG extract to the recipient fish. The appropriate amount of diluted hormone stock solution was taken in one $\mathrm{ml}$ disposable syringe. A piece of clean, soft and wet cloth was used to wrap up the fish and kept lying on foam. The accurate dose of PG extract was administered at the basal part of the dorsal fin. Needle was inserted at an angle of $45^{\circ}$ with the body. During injecting the dose was divided into two volumes and injected to the females with $6 \mathrm{~h}$ interval. All the males were injected only single dose during $2^{\text {nd }}$ injection of females. During handling of the fish more care has taken and optimum water condition were maintained to minimize stress.

\section{Single doses PG extract}

In case of $T_{1}$, single dose of $6.0 \mathrm{mg} \mathrm{PG} \mathrm{kg}^{-1}$ bw was injected in the females while the males were injected at the rate of $2.0 \mathrm{PG} \mathrm{kg}^{-1} \mathrm{bw}$. Eight male and eight female fishes were injected. The injected male and female (1:1) were placed in separate tanks. Breeding behavior and spawning activities were observed up to ovulation time. After $6,7,8$ and $10 \mathrm{~h}$ of hormonal injection, the brooders were caught and checked. No eggs can be collected from female but males were ready to release milt. 


\section{Double doses PG extract}

Females fish under $T_{2}, T_{3}$ and $T_{4}$ doses of $1.0,1.5$ and $2.0 \mathrm{mg} \mathrm{PG} \mathrm{kg}^{-1} \mathrm{bw}$, respectively was injected as first dose, while $5.0,5.5$ and $6.0 \mathrm{mg} P \mathrm{mg}^{-1} \mathrm{bw}$, respectively was injected as second dose at $6 \mathrm{~h}$ intervals. At the time of second injection of female, males under $T_{2}, T_{3}$ and $T_{4}$ were injected at the dose of 2.0, 2.5 and $3.0 \mathrm{mg} \mathrm{PG} \mathrm{kg}^{-1} \mathrm{bw}$, respectively. Eight male and eight female fishes were injected for each treatment. The injected male and female (1:1) were placed in separate spawning tanks and provided with a continuous flow of deep tube-well water through inlet of the tanks.

\section{Ovulation, collection of eggs and fertilization with milt}

After injection of PG the males and females under each treatment were kept in the separate cistern for stripping and the female was kept under observation to monitor if they exhibit any change in behaviour. The female were checked every hour after $2 \mathrm{~h}$ of $2^{\text {nd }}$ injection by gently pressing their abdomen to ascertain the ovulation. A fish was considered ovulated when there were extrusions of a few eggs upon gentle pressure on the abdomen from anterior to posterior direction. The females upon ovulation were immediately stripped to collect eggs in plastic bowl. Milt from the male fish was collected by applying slight pressure on its abdomen. The eggs and milt were mixed thoroughly in the plastic bowl with a soft and clean feather. A few drops of water were added in the bowl and was shaken gently to ensure effective fertilization. To promote fertilization salt $(\mathrm{NaCl})$ solution was added in the fertilized eggs. This solution was prepared by using $8.5 \mathrm{~g} \mathrm{NaCl}$ in $1.0 \mathrm{~L}$ of water. After the use of salt solution to the eggs, it was stirred continuously for 5 minutes to mix homogeneously. The fertilized eggs were washed several times with clean water to remove the excess milt, blood etc. The swollen eggs were transferred to incubation tank. The eggs hatched out within 44 to $48 \mathrm{~h}$ at temperature ranged from 20.0 to $22.0^{\circ} \mathrm{C}$. During incubation period, dead embryos were removed to prevent fungal growth. Number of live eggs in each group was determined within 2 to $3 \mathrm{~h}$ of fertilization. Percent ovulation was calculated using the formula as: ovulation $(\%)=($ Number of fish ovulated $/$ Total number of fish injected $) \times 100$.

\section{Determination of fertilization and hatching rates}

A batch of approximately 100 fertilized eggs was placed in each of 3 bowls of $1.25 \mathrm{~L}$ capacity to determine the fertilization and hatching rates. Soon after fertilization, the embryonic development started and the fertilized eggs assumed watery appearance or slightly transparent colour while the unfertilized ones turned whitish and opaque as the time passes. Within $6 \mathrm{~h}$ of incubation, the numbers of fertilized and unfertilized eggs from each bowl were counted based on the colour and appearance of the eggs. The fertilized eggs began to change its size and colour from yellowish to watery and transparent while unfertized eggs turned opaque and whitish in colour. After completion of hatching, the numbers of larvae of each bowl were counted. The parameters such as percent fertilization and percent hatching were recorded as indices of the effectiveness of different PG doses: The fertilization and hatching rate was calculated as: fertilization (\%) $=$ (Number of fertilized eggs / Number of total eggs) $\times 100$ and hatching $(\%)=($ Number of hatchlings $/$ Number of fertilized eggs $) \times 100$.

Statistical Analysis: The data of the effectiveness of different PG doses viz., ovulation, fertilization and hatching rate were analyzed by MS Excel computer package as descriptive values such as mean and percentage and further tested following one way ANOVA to assess significant difference between treatment groups and then using Duncan's New Multiple Range Test (DNMRT). The data were analyzed using statistical package through computer following Standard Methods (Zar, 1996).

\section{Results and Discussion}

\section{Ovulation rate}

The ovulation rate, fertilization rate, time of hatching and hatching rate following administration of $P G$ of C. carassius have been shown in Table 1. In case of single dose of PG in $T_{1}$ the dose of $6.0 \mathrm{mg} \mathrm{kg}^{-1} \mathrm{bw}$ of females did not respond. In case of double doses among the different treatments average ovulation rates 
were recorded as $96.52 \pm 2.35,88.37 \pm 3.52$ and $71.44 \pm 5.93 \%$ under the $T_{2}, T_{3}$ and $T_{4}$, respectively during the period of experiment (January). The highest ovulation rate was observed as in $T_{2}$ while the lowest was recorded in $\mathrm{T}_{3}$ and $T 4$, respectively. A significant difference on ovulation was observed among all the treatments. In case of male fish the PG dose $\left(2.0 \mathrm{mg} \mathrm{kg}^{-1}\right.$ bw of fish) was found to be satisfactory in $T_{2}$ (Fig. 2).

\section{Fertilization rate}

Average fertilization rates of eggs were recorded as $90.35 \pm 3.15,56.88 \pm 4.89$ and $55.00 \pm 3.45 \%$ under the $T_{2}, T_{3}$ and $T_{4}$, respectively. The highest fertilization rate was recorded in $T_{2}$ whereas the lowest was recorded in $T_{4}$ (Table 1 and Fig. 2). However, fertilization rate under the $T_{2}$ was significantly $(P<0.05)$ higher than that of $\mathrm{T}_{3}$ and $\mathrm{T}_{4}$.

\section{Hatching rate}

Mean effects of PG on hatching rate of eggs were observed as $78.65 \pm 2.84,45.23 \pm 3.99$ and $36.89 \pm 2.13 \%$ under the $T_{2}, T_{3}$ and $T_{4}$, respectively. The highest hatching rate was observed under the $T_{2}$ and the lowest was recorded in $T_{3}$ and $T_{4}$, respectively (Fig. 2 and Table 1).

Hatching rate of the fish under $T_{2}$ was significantly $(P<0.05)$ higher than all other treatments. Hatching time ranged from $44-48 \mathrm{~h}$ under every treatment. Incubation temperature ranged from $20.0-22.0^{\circ} \mathrm{C}$ (Table 1). Yolk sac absorption of the larvae started after $60 \mathrm{~h}$ of hatching and completed within $72 \mathrm{~h}$. After completion of yolk sac absorption of the larvae, diluted boiled yolk of chicken eggs was provided as first food for the hatchlings at $6 \mathrm{~h}$ intervals and after 3-4 meals the spawn then was ready to release in the nursery ponds.

Table 1. Details of the different doses of PG extract on ovulatory response, fertilization and hatching rates of Carassius carassius

\begin{tabular}{|c|c|c|c|c|c|c|c|c|c|c|c|c|c|c|}
\hline 这 & \multicolumn{2}{|c|}{$\begin{array}{l}\text { Weight of brood fish } \\
\text { (g) }\end{array}$} & \multicolumn{2}{|c|}{$\begin{array}{l}1^{\text {st }} \text { dose } \\
\text { (mg PG } \\
\left.\mathrm{kg}^{-1} \mathrm{bw}\right)\end{array}$} & \multirow[t]{2}{*}{$\begin{array}{c}\text { Interval of } \\
2^{\text {nd }} \text { injection } \\
\text { (h) }\end{array}$} & \multicolumn{2}{|c|}{$\begin{array}{l}2^{\text {nd do dose }} \\
\left(\mathrm{mg} \mathrm{PG} \mathrm{kg}^{-1} \mathrm{bw}\right)\end{array}$} & \multirow{2}{*}{\begin{tabular}{|c|}
$\begin{array}{c}\text { Ovulation } \\
\text { after } 2^{\text {nd }} \\
\text { injection (h) }\end{array}$ \\
no Ovulation
\end{tabular}} & \multirow[t]{2}{*}{$\begin{array}{c}\text { Ovulation } \\
\text { rate } \\
(\%) \\
\end{array}$} & \multirow[t]{2}{*}{\begin{tabular}{|c|} 
Fertilization \\
rate \\
$(\%)$ \\
\end{tabular}} & \multirow{2}{*}{\begin{tabular}{|c|}
$\begin{array}{c}\text { Hatching } \\
\text { period } \\
\text { (h) }\end{array}$ \\
- \\
\end{tabular}} & \multirow{2}{*}{\begin{tabular}{|c|c}
$\begin{array}{c}\text { Hatching } \\
\text { rate } \\
\text { (h) }\end{array}$ \\
-
\end{tabular}} & \multirow[t]{2}{*}{\begin{tabular}{|c} 
Incubation \\
Temp. \\
$\left({ }^{\circ} \mathrm{C}\right)$ \\
\end{tabular}} & \multirow[t]{2}{*}{ Remarks } \\
\hline & Female & Male & $\mathrm{F}$ & $M$ & & $\mathrm{~F}$ & $M$ & & & & & & & \\
\hline $\mathrm{T}_{1}$ & $450 \pm 3.45$ & $560 \pm 4.67$ & - & - & 6 & 6.0 & 2.0 & 6 & - & |- & - & - & & $\begin{array}{l}\text { No sign of } \\
\text { ovulation }\end{array}$ \\
\hline$\overline{T_{2}}$ & $456 \pm 2.45$ & $555 \pm 4.56$ & 1.0 & & 6 & 5.0 & 2.0 & 4 & $\begin{array}{l}96.52 \pm 2.3 \\
5^{\mathrm{a}}\end{array}$ & $90.35 \pm 3.15^{a}$ & $44-48$ & $\begin{array}{l}78.65 \pm 2 . \\
84^{\mathrm{a}}\end{array}$ & $20-22$ & $\begin{array}{l}\text { Most of male \& } \\
\text { female were } \\
\text { responded same } \\
\text { time. So } \\
\text { fertilization \& } \\
\text { hatching rate } \\
\text { was higher }\end{array}$ \\
\hline$T_{3}$ & $445 \pm 7.45$ & $568 \pm 3.40$ & 1.5 & & 6 & 5.5 & 2.5 & 3 & $\begin{array}{c}88.37 \pm 3.5 \\
2^{\mathrm{b}}\end{array}$ & $56.88 \pm 4.89^{b}$ & $44-48$ & $\begin{array}{l}45.23 \pm 3 . \\
99 b\end{array}$ & $20-22$ & $\begin{array}{l}\text { Female response } \\
\text { earlier \& most of } \\
\text { male does not } \\
\text { response same } \\
\text { time }\end{array}$ \\
\hline$\overline{T_{4}}$ & $456 \pm 6.78$ & $555 \pm 5.45$ & 2.0 & & 6 & 6.0 & 3.0 & 3 & $\begin{array}{c}71.44 \pm 5.9 \\
3 c\end{array}$ & $55.00 \pm 3.45^{b}$ & $44-48$ & $\begin{array}{l}36.89 \pm 2 . \\
13 c\end{array}$ & $20-22$ & \begin{tabular}{|l} 
Female response \\
earlier \& most of \\
male does not \\
response same \\
time
\end{tabular} \\
\hline
\end{tabular}

All values were reported as mean and standard deviation $(M \pm S D)$. Figures in the same row having the same superscripts are not significantly different $(P>0.05)$ and having different superscripts are significantly different $(P<0.05)$. 


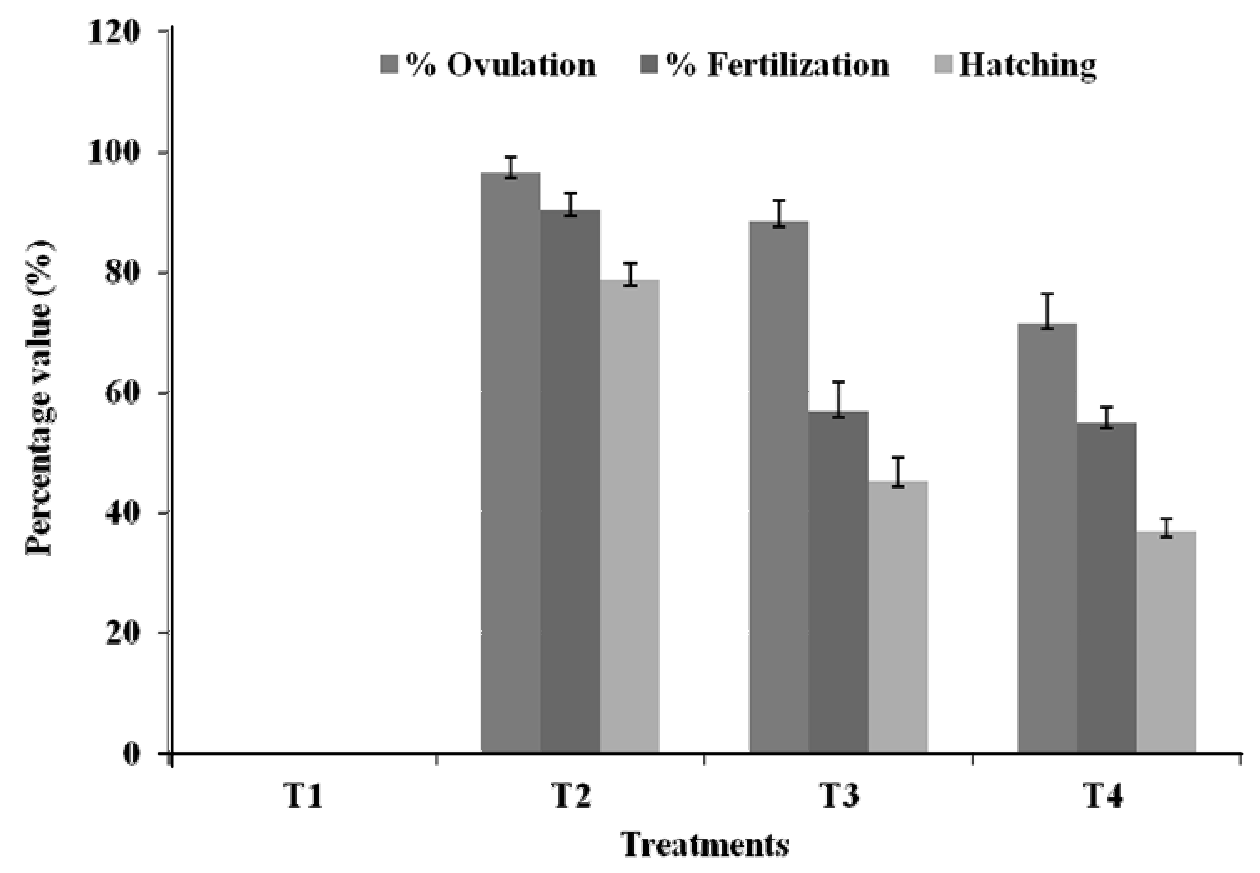

Fig. 2. Comparison of ovulation, fertilization and hatching rates of $C$. carassius during induced breeding of PG doses (vertical bars marked with the different colors are significantly different, $P<0.05$ )

The results revealed that single administration of PG extract in female $C$. carassius at the dose of $6.0 \mathrm{mg}$ PG kg-1 bw in $T_{1}$ yielded no ovulatory response but the female was good respondent fully to ovulation within $6.0 \mathrm{mg} \mathrm{PG} \mathrm{kg}{ }^{-1}$ bw when applied as double dose $\left(1^{\text {st }}\right.$ dose 1.0 and $2^{\text {nd }}$ dose $\left.5.0 \mathrm{mg} \mathrm{PG} \mathrm{kg}^{-1} \mathrm{bw}\right)$ in $\mathrm{T}_{2}$. In the case of male, amount of PG required to promote spermiation was found to be $2.0 \mathrm{mg} \mathrm{PG} \mathrm{kg}{ }^{-1}$ bw administered at the time of application of second injection to the female. The best spawning occurred under dual hormonal regime at doses of 1.0 and $5.0 \mathrm{mg} \mathrm{PG} \mathrm{kg}^{-1}$ body weight in case of female. But administration of PG extract at the rate of $7.0 \mathrm{mg} \mathrm{kg}^{-1}$ body weight $\left(1^{\text {st }}\right.$ doses of 1.5 and $2^{\text {nd }}$ doses of 5.5) in $T_{3}$ and $8.0 \mathrm{mg} \mathrm{kg}^{-1}$ bw ( $1^{\text {st }}$ doses of 2.0 and $2^{\text {nd }}$ doses of 6.0) in $T_{4}$ showed decrease in ovulation, fertilization and hatching rates. In case of higher dose of female the ovulation period decreased which resulted female laid eggs so earlier and most of males were not ready to release sperm. In case of higher dose of PG, fertilization rate was also found to be lower. Higher dose of PG sometimes causes block in reproductive vain of female. On the other hand, fertilized eggs quality was very poor and they did not hatch in case of higher dose. For this reason ovulation, fertilization and hatching rate was observed lower at higher dose and no response in ovulation in case of single dose.

In the present experiment, injection of pituitary extract at 1.0 and $5.0 \mathrm{mg} \mathrm{PG} \mathrm{kg}^{-1}$ bw of the C. carassius showed better results in ovulation, fertilization and hatching rates. Further increase in the amount of hormone doses resulted in lower reproductive performances. The doses of PG have been optimized to 1.0 and $5.0 \mathrm{mg} \mathrm{PG} \mathrm{kg}{ }^{-1}$ bw at first and second injection, respectively for female of $C$. carassius at an interval of $6 \mathrm{~h}$. Significant variation was observed in fertilization and hatching rate of $C$. carassius eggs following administration of the different doses of PG extract when increased. This apparent variation appeared to be related with the qualitative and quantitative nature of hormonal substance. A very much similar trend in the breeding performance was also observed in fishes treated with other hormonal substances (Akhtar and Bhuiyan, 2012). Successful induction of spawning in C. carassius indicated that spawners might have received hormone treatment at optimal breeding conditions. Khan and Mukhopadhyay (1975) pointed out that the success of entire operation of artificial propagation depends largely on proper selection of brood fishes which has close similarity with the present experiment. 
Accomplishment of successful spawning depends on selection of suitable pair of fish at the proper stage of ovarian development and creation of congenial spawning conditions (Nash and Shehadesh, 1980). The fish treated with the dose of $6.0 \mathrm{mg} \mathrm{PG} \mathrm{kg}^{-1}$ bw as double dose in January showed the best performance so far as the ovulation, fertilization and hatching rates are concerned. While, the fish treated with 7.0 and $8.0 \mathrm{mg} \mathrm{PG} \mathrm{kg}{ }^{-1}$ bw showed lower ovulation, fertilization and hatching rates of eggs. Since fishes of approximately similar age, size and maturity were used under the same management conditions, the difference in the result obtained was may be due to the variation in PG doses.

The water temperature ranged between 20.0 and $22.0^{\circ} \mathrm{C}$ during the study period. Breeding of major carp was performed at an ambient water temperature from 27.0 to $29.0^{\circ} \mathrm{C}$. Though water temperature ranging from 26.5 to $31.0^{\circ} \mathrm{C}$ is reported to be appropriate for spawning of major carps (Ibrahim et al., 1968) but the present studies indicated that the $C$. carassius is the winter breeder fish so the water temperature ranged $20.0-22.0^{\circ} \mathrm{C}$ was suitable for this species. Chaudhuri (1960) found that higher the water temperature lesser the spawning success. In case of carp induced breeding the range of water temperature is about $24.0^{\circ} \mathrm{C}$ to $31.0^{\circ} \mathrm{C}$ and cool and rainy days are usually conductive to induce spawning success (Chaudhuri, 1960). So, temperature and rainfall have an effect on breeding activities and results of spawning, fertilization and hatching. According to Woyhavorish and Horvath (1980) that effectiveness of dosage administered actually depend on the readiness of the females, their age, size, sensitivity amongst other factors. They also said that environmental factors such as temperature, $\mathrm{pH}$, dissolved oxygen and calmness play crucial role in ovulation and that temperature is of vital role. However, in the present study temperature ranges $20.0-22.0^{\circ} \mathrm{C}$ during January was appropriate for successful spawning of the $C$. carassius as indicated the fish is winter breeder. From the above discussion it can be said that ovulation, fertilization and hatching of $C$. carassius varies mainly due to hormone doses because all other factors were same in all treatments.

Brood stock management is one of the major aspects in induced breeding of any fish species. In hatchery management, maintenance of brood fishes for the development of modern aquaculture activities has become one of the most important concepts. Proper care of brood stock is very important for assuring good production of eggs, fry and fingerlings (Robert et al., 1982). The daily and seasonal rates of feeding of brood stock diets have direct effects on fecundity and egg size (Jones and Bromage, 1987, Bromage and Cumaranatunga, 1988). In the present study brood stock management with balanced feed comprising adequate amount of protein, lipid, and carbohydrate, especially enriched with vitamin premix the fish C. carassius attained gonadal maturity in December-January and induced breeding was conducted successfully. Upon all consideration, injection of $6.0 \mathrm{mg} \mathrm{PG} \mathrm{kg}^{-1}$ bw when applied double dose $\left(1^{\text {st }}\right.$ dose 1.0 and $2^{\text {nd }}$ dose $5.0 \mathrm{mg} \mathrm{PG} \mathrm{kg}^{-1}$ bw at $6 \mathrm{~h}$ interval) of female and $2.0 \mathrm{mg} \mathrm{PG} \mathrm{kg}^{-1}$ bw of male at single dose (at the time of second injection of female) in January showed better results. It was observed from the present study that the ovulation, fertilization and hatching rate were commercially viable for the production of fish in captive condition. Therefore the present study reveals that induced breeding of $C$. Carassius is successful through PG extract.

\section{Conclusion}

From the available references along with the present investigation on the induced breeding of $C$. carassius comparatively higher percentages of fertilization and hatching were achieved from PG hormone. It is evident from the findings that PG extract is effective in induced breeding of $C$. carassius under controlled hatchery condition. The hatchery operators may use pituitary gland (PG) at this dose for induced breeding of $C$. carassius.

\section{References}

Akhtar, J. and Bhuiyan, A.S. 2012. Efficacy of two inducing agents PG and DoM+SGnRH in induced breeding of the major carp, kalibaus (Labeo calbasu) Univ. J. Zool. Rajshahi., 31 : 23-26.

Alam, M.M and Bhuiyan, A.S. 1999. Determination of the optimum PG dose for induced spawning of Labeo rohita (Hamilton, 1822). Univ. J. Zool. Rajshahi., 18: 103-108. 
Ali, M.Y. 1967. Induced spawning of major carps in ponds by pituitary hormone injections. Agric. Int. Serv. Dhaka, 3: 2p.

Alikunhi, K.H., Vijayalakshman, M.A. and Ibrahim, K.H. 1960. Preliminary observation on the spawning on Indian carps, induced by injection of pituitary hormone. Bid. .J. Fish., 7(1): 1-19.

Bhuiyan, A.S., Musa, A.S.M. and Islam, M.K. 2008. Some observations on the induced spawning of Labeo rohita (Hamilton, 1822) by pituitary hormone injection. Bangladesh J. Life Sci., 20 (1): 89-94.

Bromage, N. and Cumaranatunga, R. 1988. Egg Production of Rainbow thought. In J.F. Muir and R.J. Robberts (eds.). Recent Advances in Aquaculture, Vol. 4, pp. 63-138. Croom Helm timber press, London.

Chaudhuri, H. 1960. Experiments on induced spawning of Indian carps with pituitary injections. Indian .J. Fish., 7(1): 20-48.

DoF 2013. National Fish Week Compendium, Department of Fisheries, Ministry of Fisheries and Livestock, Government of the People's Republic of Bangladesh, Matshya Bhaban, Dhaka, Bangladesh. pp.144.

Haque, K.A. 1975. Some observations on the induced spawning of major carps by pituitary hormone injection. Freshwater Fish. Res. Sta. Chandpur. Buli. No. 1 : 19-33.

Holopainen, I.J. and Hyvärinen, H. 1985. Ecology and Physiology of crucian carp (Carassius carassius L.). Verh. Int. Ver. Limnol., 22: 2566-2570.

Ibrahim, K.H., Bhowmik, R.M. and Panicker, G.C. 1968. Observation on the role of water temperature in artificial propagation of Indian carp. J. Inland Fish. Soc., 2: 128-131.

Islam, M.Z. and Chowdhury, A.Q. 1976. Induced spawning of major carps for commercial production of fry for fish seed in Bangladesh. Bang. J. Zool., 4(2): 51-61.

Jones, J. and Bromage, N. 1987. The influence of ration size on the reproductive performance of female rainbow trout. In: Idler, L. Crim and J. walsh (eds.). Reproductive physiology of fish., pp. 22.

Khan, H.A. and Mukhopadhyay, S.K. 1975. Production of stocking material of some air breathing fishes by hypo-physation. J. Inland Fish. Soc. India., 7: 156-161.

Kobayashi M., Sorensen P.W. and Stacey, N.E. 2002. Hormonal and pheromonal control of spawning in the goldfish. Fish. Physiol. Biochem., 26: 71-84.

Nash, C.E. and Shehadesh, Z.H. 1980. Review of Breeding and Propagation Technique for Grey Mullet, Mugil Cephalus L. ICLARM Studies 3, ICLARM, Manila, Philippines, 87pp.

Robert, G.P., Melweing, I.B., Orme, L.E., Craren, J.P., Fowler, L.G. and Leonard, J.R. 1982. Fish Hatchery Management. pp. 131199.

Sinha, V.R.P. 1971. Induced spawning in carp with fractional fish pituitary extract. J. Fish. Biol. Lond., 3: 263-272.

Woynarovich, E. and Horvath, L. 1980: The artificial propagation of warm water fin fishes-a manual for extension. FAO Fish. Technical Paper 1: 183.

Zar, Z.H. 1996. Biostatistical Analysis (3rd edition). Prinentice Hall Inc., N.J. 662 pp. 